\title{
An Efficient Synthesis of D-Galactose-Based Multivalent Neoglycoconjugates
}

\author{
Saulo F. de Andrade, ${ }^{a}$ Rute C. Figueiredo, ${ }^{c}$ José D. de Souza Filho ${ }^{a}$ and Ricardo J. Alves ${ }^{*, b}$ \\ ${ }^{a}$ Departamento de Química, Instituto de Ciências Exatas and ${ }^{b}$ Faculdade de Farmácia, Universidade \\ Federal de Minas Gerais, Av. Antônio Carlos, 6627, 31270-901 Belo Horizonte-MG, Brazil \\ ${ }^{c}$ Universidade Federal de Ouro Preto, Campus Morro do Cruzeiro, s/n, Bairro Bauxita, \\ 35400-000 Ouro Preto-MG, Brazil.
}

\begin{abstract}
Este trabalho descreve a síntese de neoglicoconjugados diméricos, triméricos e tetraméricos derivados de D-galactose. O ligante monossacarídico foi preparado em cinco etapas utilizando-se a modificação de Doebner da reação de Knoevenagel na etapa de extensão da cadeia lateral. O ligante foi acoplado a 1,4-butanodiamina, tris-(2-etilamino)amina, pentaeritritiltetramina e dendrímeros PAMAM (núcleo 1,4-butanodiamina G0 e núcleo 1,12-dodecanodiamina G0). Os glicodendrímeros desprotegidos foram purificados por cromatografia por exclusão de tamanho (SEC). Esta foi a única etapa em que um método cromatográfico foi empregado em toda rota sintética. Essa é uma estratégia nova e eficiente para a preparação de neoglicoconjugados.
\end{abstract}

In this work, the synthesis of dimeric, trimeric and tetrameric D-galactose-based neoglycoconjugates is reported. The monosaccharide ligand was prepared in 5 straightforward steps from D-galactose using the Doebner modification of the Knoevenagel reaction for chain elongation. The ligand was coupled to 1,4-butanediamine, tris-(2-ethylamino)amine, pentaerythrityltetramine and PAMAM dendrimers (1,4-butanodiamine core G0 and 1,12-dodecanediamine core G0). The unprotected glycodendrimers were purified by size-exclusion chromatography (SEC). This was the only step in which a chromatographic method was employed throughout the synthetic route. This is a new and efficient strategy for the preparation of neoglycoconjugates.

Keywords: glycodendrimers, D-galactose, synthesis, pentaerythrityltetramine, PAMAM

\section{Introduction}

Glycodendrimers are neoglycoconjugates that can be considered as bioisosters of glycoproteins, ${ }^{1}$ as they can mimic the multivalent interactions of lectin-carbohydrate in several adhesion processes. The ability of glycodendrimers to present multivalent interactions with lectins as compared to a monovalent ligand is referred to as "cluster effect". 2,3 Increasing multivalency, however, does not always result in higher affinity. Several low molecular weight and low valence glycodendrimers (dimers, trimers and tetramers) are very potent and, sometimes, even more potent than higher valency analogs in their interaction with lectins..$^{4-7}$

This is very important from the medicinal chemistry point of view, since low molecular dendrimers are expected to have favorable physicochemical properties comparing to the high molecular weight, multivalent ones.

*e-mail: ricardodylan@farmacia.ufmg.br
Efforts for blocking microbial lectins have driven carbohydrate chemists towards the production of original molecules specifically designed for their anti-adhesion potency. For example, L-fucoside and D-galactose-coated glycodendrimers were effective in blocking $P$. aeruginosa lectin PA-IL and PA-IIL, ${ }^{8}$ while D-mannose-coated ones were able to inhibit the binding of $E$. coli to epithelial cells. ${ }^{9}$ Recently, anti-inflammatory activity was reported for D-glucose-based glycodendrimers. ${ }^{10}$

Due to the importance of neoglycoconjugates for these biological studies, there is a constant need for straightforward methods for the synthesis and purification of these compounds. Herein, we present an efficient synthesis of the glycodendrimers 1-5 (Figure 1).

\section{Results and Discussion}

Amide bonds are one of the most useful connections to attach a carbohydrate moiety to a core or dendrimer. ${ }^{11}$ 


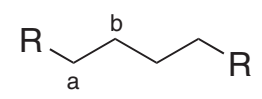

Glycodendrimer 1<smiles>[R]CCN(CC[R])CC[R]</smiles>

Glycodendrimer 2<smiles>[R]CC([R])(C[R])C[R]</smiles>

Glycodendrimer 3

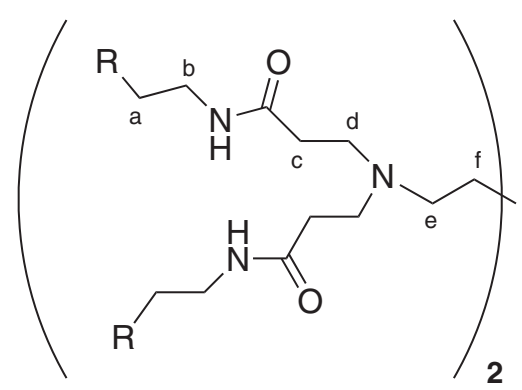

Glycodendrimer 4

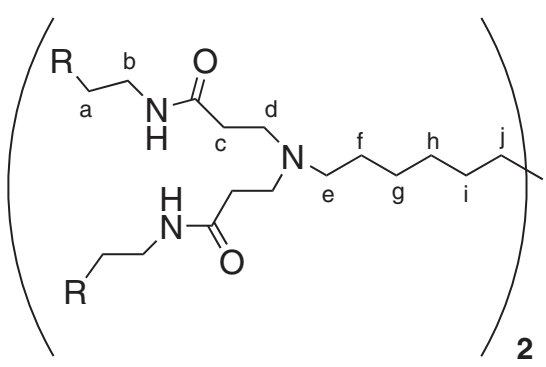

Glycodendrimer 5<smiles>[2H]P=C(C=Cc1ccc(OC2O[C@H](CO)[C@@H](O)[C@H](O)[C@H]2O)c(OC)c1)NC</smiles>

Figure 1. Chemical structures of glycodendrimers 1-5.

Hence, the preparation of a carboxylic acid glycoside is essential to couple with polyamine cores or dendrimers. Glycodendrimers 1-5 were obtained from the galactopyranoside $\mathbf{9}$ and the commercially available cores 1,4-butanediamine and tris-(2-ethylamino) amine; commercially available dendrimers PAMAM (1,4-butanodiamine core G0 and 1,12-dodecanediamine core G0) and synthetic pentaerythrityltetramine (Scheme 1). The monosaccharide ligand $\mathbf{9}$ was easily prepared on multigram scale in 4 straightforward steps from peracetylated D-galactose. Compound $\mathbf{1 0}$ was coupled to the cores or dendrimers followed by the methanolysis. ${ }^{12}$ This afforded the glycodendrimers 1-5.

Pentaerythrityltetramine was prepared in the form of the corresponding tetrahydrochloride from pentaerythritol by a modification of previous report in three steps (Scheme 2). ${ }^{13}$

\section{Preparation of glycoside $\mathbf{9}$}

The known compound $\mathbf{8}$ was prepared in 3 steps by a modification of previous report. ${ }^{14}$ Initially, the treatment of peracetylated galactose with $\mathrm{HBr}$ provided the galactopyranosyl bromide $\mathbf{6} .{ }^{15}$ Glycosylation of the inexpensive and commercially available vanillin with $\mathbf{6}$, under basic conditions, furnished the glycoside 7 (68\% overall yield after recrystallization). ${ }^{16}$ Glycoside 7 was reacted with malonic acid under Doebner conditions to give the known compound $\mathbf{8}$ in $96 \%$ yield. ${ }^{17,18}$

Finally, hydrogenation of $\mathbf{8}$ using $\mathrm{H}_{2} / \mathrm{Pd}-\mathrm{C}$ afforded the novel glycoside 9 in a pure form $\left(90 \%\right.$ yield) ${ }^{18}$ In the ${ }^{1} \mathrm{H}$ NMR (nuclear magnetic resonance) spectrum of $\mathbf{9}$ (Figure 2), the signals of the aromatic protons were detected at $\delta$ 7.05-6.72. Galactopyranoside ring proton signals were observed at $\delta$ 5.49-3.97. The protons of the methoxy group were observed at $\delta 3.81$, methylene units at $\delta 2.91-2.66$ and methyls of the acetate groups at $\delta 2.18-2.01$. Thus, compound 9 could be easily prepared in pure form on a gram scale without using any column chromatography.

\section{Preparation of glycodendrimers 1-5}

The carboxy group of $\mathbf{9}$ was activated with $N$-hydroxysuccinimide (NHS) using 1-ethyl-3-(3dimethylaminopropyl)carbodiimide hydrochloride 


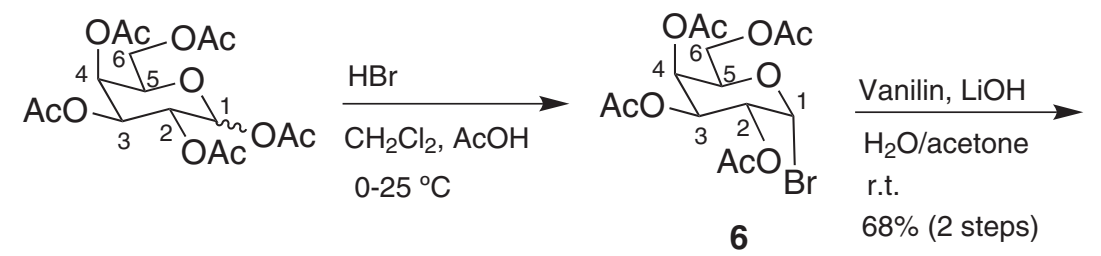

6

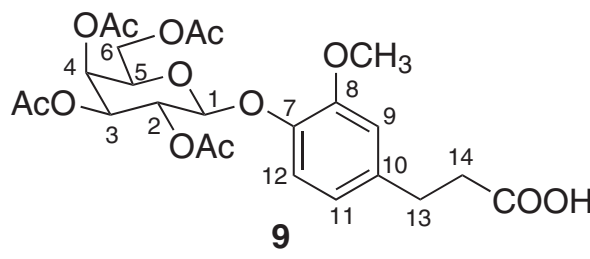

EDC, NHS $\mathrm{CH}_{2} \mathrm{Cl}_{2}$, r.t., $100 \%$

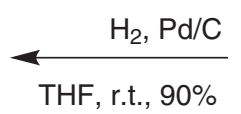

THF, r.t., $90 \%$

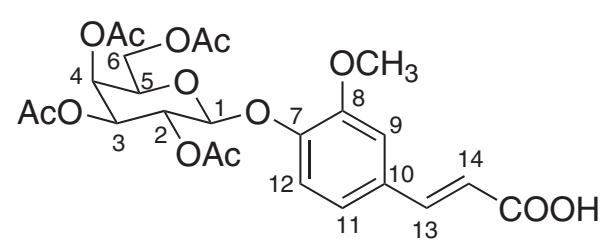

8

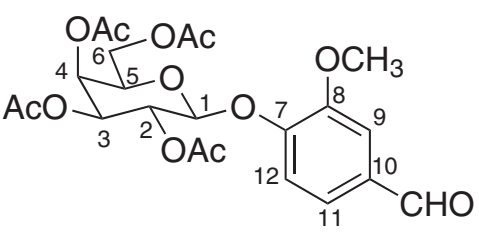

7

Malonic acid, pyperidine Pyridine, $95{ }^{\circ} \mathrm{C}, 96 \%$

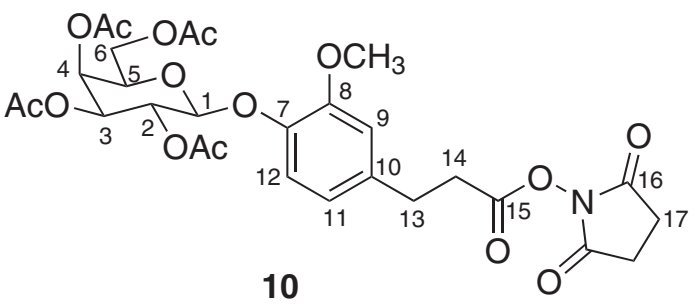

1 - Core/dendrimer, $\mathrm{CH}_{2} \mathrm{Cl}_{2}$, r.t.

$2-\mathrm{MeOH}, \mathrm{MeONa}, 0^{\circ} \mathrm{C}$

$75-94 \%$

Scheme 1.<smiles>OCC(CO)(CO)CO</smiles>

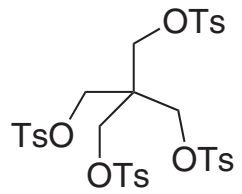

11

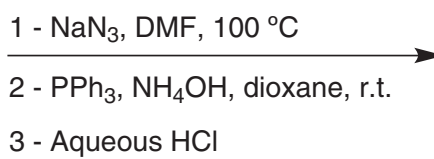

$62 \%$ (3 steps)
Glycodendrimers 1 - 5

Scheme 2.

(EDC) to give 10. ${ }^{19}$ The reaction of $\mathbf{1 0}$ in small excess (1.2 equivalent per mol of amino group) with cores or dendrimers followed by $O$-deacetylation under Zemplén's conditions gave glycodendrimers 1-5 in $75-94 \%$ yield, as described in the Experimental section..$^{20}$ The excess of activated ester $\mathbf{1 0}$ was removed by size exclusion chromatography (SEC) performed using $\mathrm{MeOH} / \mathrm{H}_{2} \mathrm{O}(1: 1)$ as mobile phase. The Sephadex column could be efficiently recycled by washing with $100 \mathrm{~mL}$ of the mobile phase.

\section{Glycodendrimers characterization}

Here, the analysis of the most complex structure glycodendrimer $\mathbf{5}$ is exemplified. In the ${ }^{1} \mathrm{H}$ NMR of $\mathbf{5}$
(Figure 3$)$, the assignments of the $\mathrm{NHC}=\mathrm{O}(\delta$ 7.92-7.86), $\mathrm{H}-1(\delta 4.78), \mathrm{H}-9\left(\delta\right.$ 6.81) $\mathrm{OC}_{3}(\delta 3.73), \mathrm{H}-4(\delta 3.69)$, $\mathrm{H}-3(\delta 3.38)$, Ha and $\mathrm{Hb}(\delta 3.07)$, Hf $(\delta 1.33)$ and $\mathrm{Hg}-\mathrm{j}$ $(\delta$ 1.07) were made based on chemical shift, coupling constant, multiplicity and integral values.

Comparing the integral of galactopyranoside proton signals (e.g. H-1) with dendrimer proton signals (e.g. Ha), it was possible to establish the proportion of the sugar units related to the dendrimer nucleus (1:2 ratio in this case). Besides, the HMBC contour map allowed establishing unequivocally the correlation between the carbonyl carbon of the carbohydrate residue with Ha protons.

The assignments for $\mathrm{H}-2$ and He were based on COSY contour map. Correlations between $\mathrm{H}-1(\delta 4.78) / \mathrm{H}-2$ 


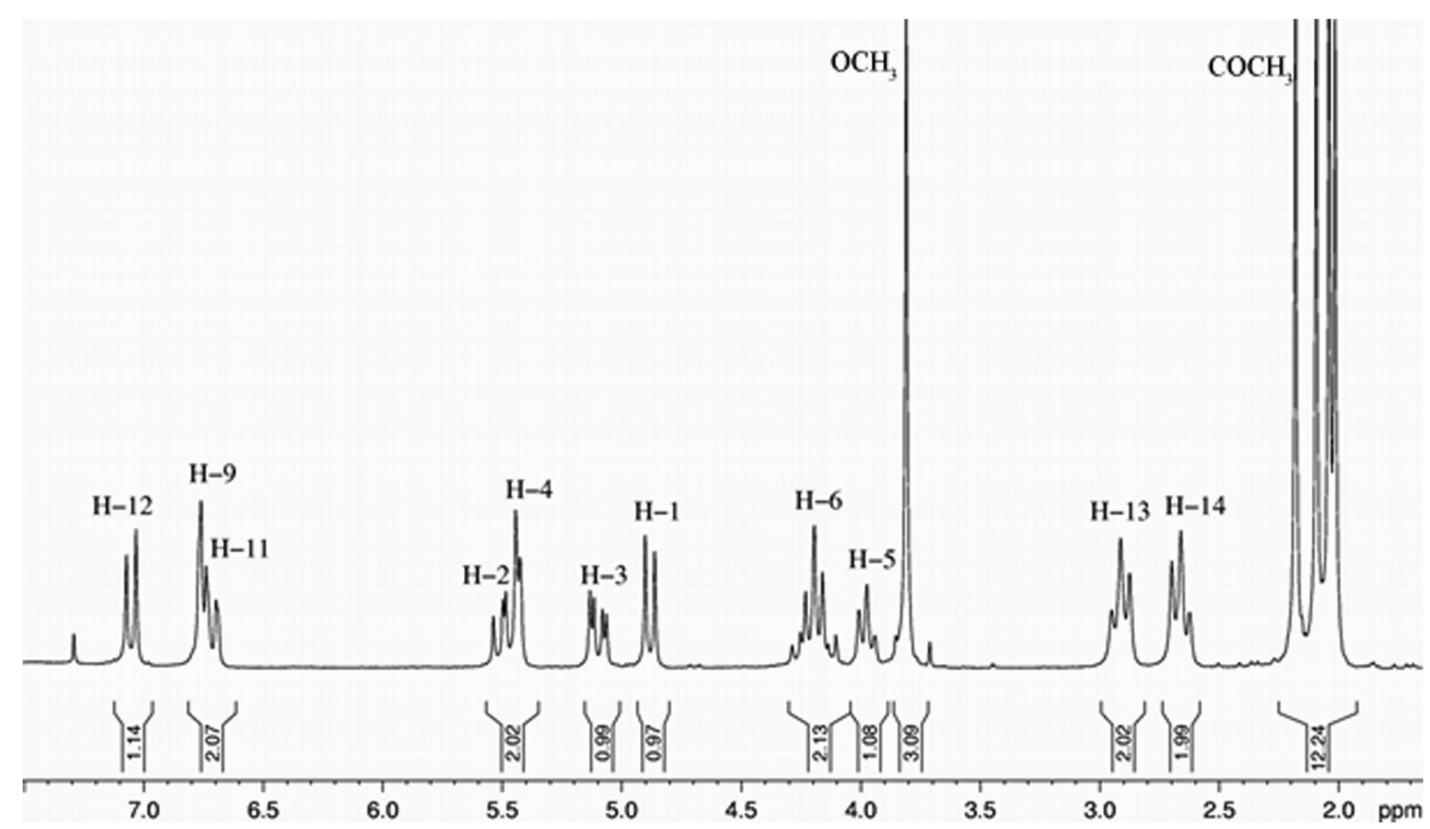

Figure 2. ${ }^{1} \mathrm{H}$ NMR spectrum $\left(\mathrm{CDCl}_{3}, 200 \mathrm{MHz}\right)$ of 9.

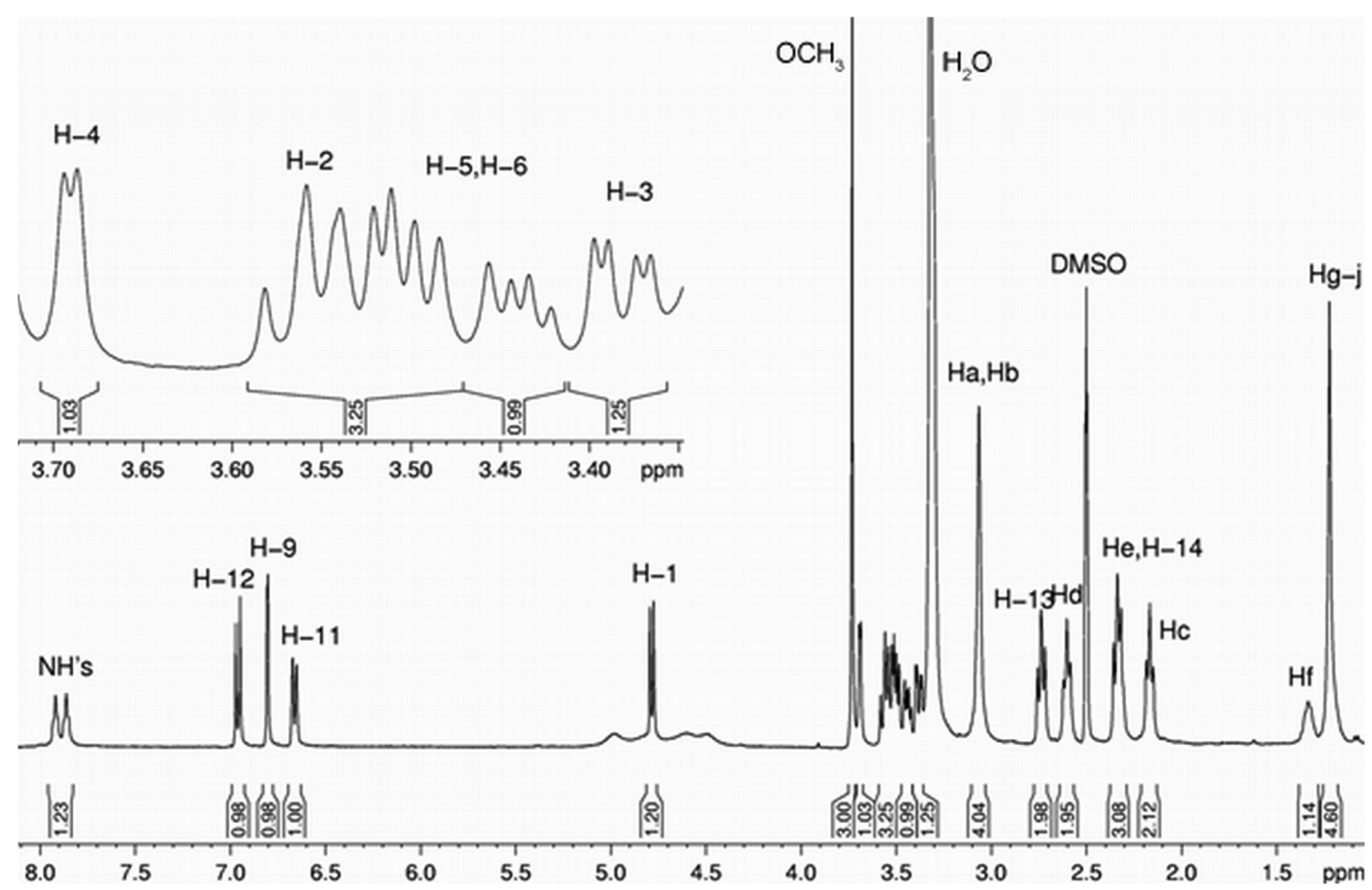

Figure 3. ${ }^{1} \mathrm{H}$ NMR spectrum (DMSO- $d_{6}, 400 \mathrm{MHz}$ ) of glycodendrimer 5 .

$(\delta 3.56)$ and $\mathrm{Hf}(\delta 1.33) / \mathrm{He}(2.36-2.32)$ were observed. Besides, most carbons were assigned using HSQC. Cross-peaks between H-1 $(\delta 4.78) / \mathrm{C}-1(\delta$ 100.9), H-2 $(\delta$ $3.56) / \mathrm{C}-2(\delta 70.3), \mathrm{H}-3(\delta 3.38) / \mathrm{C}-3(\delta 73.5), \mathrm{H}-4(\delta 3.69) /$ C-4 $(\delta$ 68.0), H-9 $(\delta 6.81) / \mathrm{C}-9(\delta 122.8), \mathrm{Ha}(\delta 3.07) / \mathrm{Ca}$ (38.3), $\mathrm{Hb}(\delta 3.07) / \mathrm{Cb}(38.3), \mathrm{He}(\delta 2.36-2.32) / \mathrm{Ce}(\delta 52.8)$, $\mathrm{Hf}(\delta 1.33) / \mathrm{Cf}(\delta$ 26.6), $\mathrm{Hg}-\mathrm{Hj}(\delta$ 1.22)/Cg-Cj $(\delta 27.0)$ and $\mathrm{OCH}_{3}(\delta 3.73) / \mathrm{OCH}_{3}(\delta 55.6)$ were detected. HMBC (heteronuclear multiple bond correlation) map was used to assign non-hydrogenated carbons C-7, C-8 and C-10. Some important ${ }^{3} \mathrm{~J}$ correlations were observed between $\mathrm{H}-1(\delta$ 4.78)/C-7 ( $\delta 144.8), \mathrm{OC}_{3}(\delta 3.73) / \mathrm{C}-8(\delta$ 148.8) and $\mathrm{H}-14(\delta$ 2.36-2.32)/C-10 (135.0).

The analysis by electrospray ionization mass spectroscopy (ESI-MS) was also conducted. Interestingly, the ESI-MS spectra of compounds 3-5 give peaks with 
fractional values $(m / z ; \mathrm{z}=2)$. This is assigned to dicationic species $\left[\mathrm{M}+2 \mathrm{Na}^{+}\right]$for compounds $\mathbf{3}-\mathbf{4}$ and $\left[\mathrm{M}+2 \mathrm{H}^{+}\right]$for 5. This is a common fact in ESI-MS. ${ }^{21}$

2D spectra (COSY, HSQC and HMBC) and mass spectrum are available in the Supplementary Information (SI) section.

\section{Conclusions}

An efficient access to glycodendrimers was demonstrated in this work. The synthesis was performed in few steps using cheap reactants in $44-55 \%$ overall yields. This synthetic strategy can be extended to other sugars and aromatic aldehydes as a general method of obtaining low molecular weight glycodendrimers.

\section{Experimental}

\section{Material and methods}

Melting points were determined on Microquímica MQAPF 301 apparatus. IR spectra were recorded on a Spectrum One, Perkin-Elmer ATR system. The ${ }^{1} \mathrm{H}$ and ${ }^{13} \mathrm{C}$ NMR spectra were obtained on a Bruker Avance DPX-200 or DRX-400. The proton and carbon chemical shifts $(\delta)$ are given with respect to TMS (tetramethylsilane). The assignments were based on COSY, DEPT-135, HSQC and HMBC experiments. Optical rotations were measured on an ADP220 Bellinghan + Stanley Ltd polarimeter. Mass spectra were recorded with a Waters Quattro LC triple quadrupolar mass spectrometer. Thin layer chromatography was performed using silica gel $60 \mathrm{G}$ Merck and $15 \%$ ethanolic $\mathrm{H}_{2} \mathrm{SO}_{4}$ (v/v) was employed for the revelation of the spots. Size-exclusion chromatography (SEC) was performed using Sephadex LH-20 (25-100 $\mu \mathrm{m}$ ). The reagents were obtained from commercial suppliers and were used without further purification.

\section{4-Formyl-2-methoxyphenyl 2,3,4,6-tetra-O-acetyl- $\beta$-D-galactopyranoside 7}

A $48 \%$ of an $\mathrm{HBr}$ aqueous solution $(\mathrm{m} / \mathrm{m} ; 24.7 \mathrm{~mL}$, $0.218 \mathrm{~mol}$ ) was added to an ice-cold magnetically stirred acetic anhydride $(100 \mathrm{~mL}, 1.06 \mathrm{~mol})$ by means of an addition funnel. The resulting solution was added to an ice-cold magnetically stirred solution of 1,2,3,4,6-penta$O$-acetyl- $\alpha, \beta$-galactopyranoside $(10 \mathrm{~g}, 25.6 \mathrm{mmol})$ in dichloromethane $(75 \mathrm{~mL})$ by means of an addition funnel. The mixture was warmed to room temperature. After $2 \mathrm{~h}$, TLC analysis $\left(9: 1 \mathrm{CH}_{2} \mathrm{Cl}_{2} / \mathrm{EtOAc}\right)$ showed that the reaction was complete. The mixture was extracted with dichloromethane $(3 \times 50 \mathrm{~mL})$. The combined organic layers were washed with a saturated aqueous solution of sodium bicarbonate to remove the acid followed by the saturated aqueous brine solution. The organic phase was dried with sodium sulfate, filtered and concentrated to give 2,3,4,6-tetra- $O$-acetyl- $\alpha$-D-galactopyranosyl bromide $\mathbf{6}$ as a colorless oil (10.61 g, 100\% yield) which was used without further purification.

To a solution of $\mathrm{LiOH} . \mathrm{H}_{2} \mathrm{O}(3.06 \mathrm{~g}, 73 \mathrm{mmol})$ in water $(23 \mathrm{~mL})$, it was added 4-hydroxy-3-methoxybenzaldehyde $(12.16 \mathrm{~g}, 80 \mathrm{mmol})$ and the mixture was stirred for $10 \mathrm{~min}$. Then, a solution of $6(10.52 \mathrm{~g})$ in acetone $(30 \mathrm{~mL})$ was added with stirring. After $2 \mathrm{~h}$, TLC analysis $\left(9: 1 \mathrm{CH}_{2} \mathrm{Cl}_{2} / \mathrm{EtOAc}\right)$ showed the completion of the reaction. Later, acetone was removed under reduced pressure and water $(50 \mathrm{~mL})$ was added to the resulting mixture. The aqueous phase was extracted with dichloromethane $(2 \times 50 \mathrm{~mL})$. The combined organic layers were washed with $1 \mathrm{~mol} \mathrm{~L}^{-1}$ aqueous $\mathrm{NaOH}(3 \times 100 \mathrm{~mL})$ and with water to $\mathrm{pH} 7$. The organic phase was dried with anhydrous sodium sulfate, filtered and concentrated. The crude product was dissolved in acetone $(5 \mathrm{~mL})$, water $(200 \mathrm{~mL})$ was added and the solid formed was collected by filtration to give 7 as a white solid ( $8.52 \mathrm{~g}, 68 \%$ yield, 2 steps): $\mathrm{mp} 123-124^{\circ} \mathrm{C}$; $[\alpha]_{\mathrm{D}}^{21}-24.0(c \mathrm{1} .0, \mathrm{MeOH}) ; \mathrm{IR} \quad \mathrm{v} / \mathrm{cm}^{-1} 2867$ and 1693 (aldehyde) 1752, 1740 and 1224 (ester) 1588 and 1515 (Aryl); ${ }^{1} \mathrm{H} \mathrm{NMR}\left(\mathrm{CDCl}_{3}, 200 \mathrm{MHz}\right) \delta 9.89(\mathrm{~s}, 1 \mathrm{H}, \mathrm{C} \underline{\mathrm{HO}})$, 7.44-7.41 (m, 2H, H-9 and H-11), 7.24 (d, $1 \mathrm{H}, J_{11,12} 8.4 \mathrm{~Hz}$, $\mathrm{H}-12), 5.56\left(\mathrm{dd}, 1 \mathrm{H}, J_{1,2} 8.0 \mathrm{~Hz}\right.$ and $\left.J_{2,3} 10.2 \mathrm{~Hz}, \mathrm{H}-2\right), 5.47$ $\left(\mathrm{d}, 1 \mathrm{H}, J_{3,4} 3.2 \mathrm{~Hz}, \mathrm{H}-4\right), 5.13\left(\mathrm{dd}, 1 \mathrm{H}, J_{2,3} 10.2 \mathrm{~Hz}\right.$ and $\left.J_{3,4} 3.2 \mathrm{~Hz}, \mathrm{H}-3\right), 5.07$ (d, 1H, $\left.J_{1,2} 8.0 \mathrm{~Hz}, \mathrm{H}-1\right), 4.30-4.05$ (m, 3H, H-5, H-6 and H-6'), 3.90 (s, 3H, $\mathrm{OC}_{3}$ ), 2.18, 2.08, 2.06, $2.02\left(\mathrm{~s}, 12 \mathrm{H}, \mathrm{COC}_{3}\right) ;{ }^{13} \mathrm{C} \mathrm{NMR}\left(\mathrm{CDCl}_{3}\right.$; $50 \mathrm{MHz}) \delta 190.8$ (ㄷO); $170.2 ; 170.1 ; 169.3\left(\underline{\mathrm{COCH}_{3}}\right)$; 151.2; 150.8 (C-7 and C-8); 132.6 (C-10); 125.3 (C-11); 117.7 (C-9); 110.6 (C-12); 100.2 (C-1); 71.1 (C-3); 70.4 (C-5); 68.3 (C-2); 66.7 (C-4); 61.2 (C-6); $56.0\left(\mathrm{OCH}_{3}\right)$; $20.5\left(\mathrm{COCH}_{3}\right)$.

\section{4-E-[(2-Carboxy)ethenyl]-2-methoxyphenyl 2,3,4,6-tetra- $O$-acetyl- $\beta$-D-galactopyranoside 8}

A solution of $7(2.0 \mathrm{~g}, 4.15 \mathrm{mmol})$, malonic acid $(2.6 \mathrm{~g}, 25 \mathrm{mmol})$ in a mixture of pyridine $(6.5 \mathrm{~mL})$ and pyperidine $(0.5 \mathrm{~mL})$ was stirred at $95{ }^{\circ} \mathrm{C}$. After $3 \mathrm{~h}$, TLC analysis (1:1 hexane/EtOAc) showed that the reaction was complete. The mixture was cooled in an ice-water bath and acidified to $\mathrm{pH} 1-2$ by the slow addition of $6 \mathrm{~mol} \mathrm{~L}^{-1}$ aqueous $\mathrm{HCl}$. The resulting suspension was extracted with dichloromethane $(2 \times 50 \mathrm{~mL})$. The combined organic layers were washed with water to $\mathrm{pH} 7$, dried with sodium sulfate, 
filtered and concentrated to afford a amorphous white solid (2.17 g, 96\% yield): $\mathrm{mp} 77-80^{\circ} \mathrm{C} ;[\alpha]_{\mathrm{D}}^{21}-10\left(c 1.0, \mathrm{CHCl}_{3}\right)$; IR $v / \mathrm{cm}^{-1} 3000$ and 1686 (carboxylic acid), 1744 (ester), 1631 (olefin); ${ }^{1} \mathrm{H} \mathrm{NMR}\left(\mathrm{CDCl}_{3}, 200 \mathrm{MHz}\right) \delta 7.71(\mathrm{~d}, 1 \mathrm{H}$, $\left.J_{13,14} 15.8 \mathrm{~Hz}, \mathrm{H}-13\right), 7.12-7.09$ (m, 3H, H-9, H-11 and H-12), 6.35 (d, 1H, J $\left.{ }_{13,14} 15.8 \mathrm{~Hz}, \mathrm{H}-14\right), 5.53$ (dd, 1H, $J_{1,2} 8.0 \mathrm{~Hz}$ and $\left.J_{2,3} 10.4 \mathrm{~Hz}, \mathrm{H}-2\right), 5.45\left(\mathrm{~d}, 1 \mathrm{H}, J_{3,4} 3.1 \mathrm{~Hz}\right.$, $\mathrm{H}-4), 5.12$ (dd, 1H, $J_{2,3} 10.4 \mathrm{~Hz}$ and $J_{3,4} 3.1 \mathrm{~Hz}, \mathrm{H}-3$ ), 4.98 (d, 1H, $\left.J_{1,2} 8.0 \mathrm{~Hz}, \mathrm{H}-1\right)$, 4.35-4.00 (m, 3H, H-5, H-6 and H-6'), 3.86 (s, 3H, OC${ }_{3}$ ), 2.18, 2.09, 2.05, 2.02 (4s, 12H, $\left.\mathrm{COCH}_{3}\right) ;{ }^{13} \mathrm{C} \mathrm{NMR}\left(\mathrm{CDCl}_{3} ; 50 \mathrm{MHz}\right) \delta 171.9 ; 170.6 ; 170.5$; $169.7\left(\mathrm{COCH}_{3}\right.$ and $\left.\underline{\mathrm{COOH}}\right) ; 150.8$ (C-8); 148.5 (C-7); 146.4 (C-13); 130.6 (C-10); 122.3 (C-12); 119.2 (C-11); 116.7 (C-14); 111.7 (C-9); 100.9 (C-1); 71.2; 70.8 (C-3 and $\mathrm{C}-5) ; 68.7(\mathrm{C}-2) ; 67.0(\mathrm{C}-4) ; 61.5(\mathrm{C}-6) ; 56.2\left(\mathrm{OCH}_{3}\right)$; $20.8\left(\mathrm{COCH}_{3}\right)$.

4-(2-Carboxyethyl)-2-methoxyphenyl 2,3,4,6-tetra-O-acetyl$\beta$-D-galactopyranoside 9

To solution of $8(0.5 \mathrm{~g}, 0.95 \mathrm{mmol})$ in $\mathrm{THF}$ (tetrahydrofuran, $5.0 \mathrm{~mL})$, it was added $\mathrm{Pd} / \mathrm{C}(0.1 \mathrm{~g})$. The mixture was stirred under hydrogen atmosphere (1 atm) for $24 \mathrm{~h}$. The catalyst was removed by filtration and the solvent evapored under reduced pressure to afford a white solid (0.45 g, 90\% yield): $\mathrm{mp} 77-78{ }^{\circ} \mathrm{C}$; $[\alpha]_{\mathrm{D}}^{21}-8$ (c 1.0, $\mathrm{CHCl}_{3}$ ); IR v/cm 3000 and 1743 (carboxylic acid), 1743 (ester); ${ }^{1} \mathrm{H}$ NMR $\left(\mathrm{CDCl}_{3}, 200 \mathrm{MHz}\right) \delta 7.05\left(\mathrm{~d}, 1 \mathrm{H}, J_{11,12}\right.$ $8.1 \mathrm{~Hz}, \mathrm{H}-12), 6.76$ (s, 1H, H-9), 6.72 (d, 1H, $J_{11,12} 8.1 \mathrm{~Hz}$, $\mathrm{H}-11), 5.49$ (dd, $1 \mathrm{H}, J_{1,2} 7.9 \mathrm{~Hz}$ and $\left.J_{2,3} 10.5 \mathrm{~Hz}, \mathrm{H}-2\right)$, 5.44 (d, 1H, $\left.J_{3,4} 3.4 \mathrm{~Hz}, \mathrm{H}-4\right), 5.1$ (dd, $1 \mathrm{H}, J_{2,3} 10.5 \mathrm{~Hz}$ and $\left.J_{3,4} 3.4 \mathrm{~Hz}, \mathrm{H}-3\right), 4.88$ (d, 1H, $\left.J_{1,2} 7.9 \mathrm{~Hz}, \mathrm{H}-1\right), 4.29-4.1$ (m, 2H, H-6 and H-6'), 3.97 (t, 1H, $\left.J_{5,6} 6.6 \mathrm{~Hz}, \mathrm{H}-5\right), 3.81$ $\left(\mathrm{s}, 3 \mathrm{H}, \mathrm{OCH}_{3}\right), 2.91\left(\mathrm{t}, 2 \mathrm{H}, J_{13,14} 7.4 \mathrm{~Hz}, \mathrm{H}-13\right), 2.66$ (t, $\left.2 \mathrm{H}, J_{13,14} 7.4 \mathrm{~Hz}, \mathrm{H}-14\right), 2.18,2.09,2.04,2.01$ (4s, 12H, $\left.\mathrm{COCH}_{3}\right) ;{ }^{13} \mathrm{C} \mathrm{NMR}\left(\mathrm{CDCl}_{3} ; 50 \mathrm{MHz}\right) \delta 178.0(\underline{\mathrm{COOH}})$; $170.4 ; 170.3 ; 170.2 ; 169.5\left(\mathrm{COCH}_{3}\right) ; 150.4(\mathrm{C}-8) ; 144.6$ (C-7); 136.8 (C-10); 120.2; 120.0 (C-11 and C-12); 112.8 (C-9); 101.3 (C-1); 70.7 (C-3 and C-5); 68.7 (C-2); 66.9 (C-4); 61.2 (C-6); $55.9\left(\mathrm{OCH}_{3}\right) ; 35.5$ (C-14); 30.2 (C-13); $20.5\left(\mathrm{COCH}_{3}\right)$.

General procedure for the synthesis of D-galactose-based dendrimers

A suspension of $9(1.0 \mathrm{~g}, 1.90 \mathrm{mmol}), \mathrm{EDC}(0.6 \mathrm{~g}$, $3.04 \mathrm{mmol})$, NHS $(0.350 \mathrm{~g}, 3.04 \mathrm{mmol})$ in dichloromethane $(20 \mathrm{~mL})$ was stirred at room temperature. After $3 \mathrm{~h}$, TLC analysis (3:7 hexane/EtOAc) showed that the reaction was complete. To the solution, it was added dichloromethane $(30 \mathrm{~mL})$. The organic phase was washed with brine $(2 \times 50 \mathrm{~mL})$, dried with sodium sulfate and concentrated to give 4-[[[2-succinimid-1-yl)oxy] carbonyl]ethyl]-2-methoxyphenyl 2,3,4,6-tetra- $O$-acetyl$\beta$-D-galactopyranoside $\mathbf{1 0}$ as a colorless foam $(1.17 \mathrm{~g})$ which was used without further purification: IR $\mathrm{v} / \mathrm{cm}^{-1}$ 1734 and 1210 (ester) 1594 (Aryl); ${ }^{1} \mathrm{H} \mathrm{NMR}\left(\mathrm{CDCl}_{3}\right.$, $200 \mathrm{MHz}) \delta 7.07$ (d, 1H, $\left.J_{11,12} 8.1 \mathrm{~Hz}, \mathrm{H}-12\right), 6.77$ (s, $1 \mathrm{H}, \mathrm{H}-9), 6.73$ (d, 1H, J $\left.{ }_{11,12} 8.1 \mathrm{~Hz}, \mathrm{H}-11\right), 5.49$ (dd, 1H, $J_{1,2} 8.0 \mathrm{~Hz}$ and $\left.J_{2,3} 10.6 \mathrm{~Hz}, \mathrm{H}-2\right), 5.43\left(\mathrm{~d}, 1 \mathrm{H}, J_{3,4} 3.5 \mathrm{~Hz}\right.$, H-4), 5.09 (dd, $1 \mathrm{H}, J_{2,3} 10.6 \mathrm{~Hz}$ and $J_{3,4} 3.5 \mathrm{~Hz}, \mathrm{H}-3$ ), 4.88 (d, 1H, $\left.J_{1,2} 8.0 \mathrm{~Hz}, \mathrm{H}-1\right), 4.28-4.10$ (m, 2H, H-6 and H-6'), 3.97 (t, 1H, H-5, J $\left.{ }_{5,6} 6.5 \mathrm{~Hz}\right), 3.82$ (s, 3H, OC$\left.{ }_{3}\right)$, $2.98\left(\mathrm{t}, 2 \mathrm{H}, J_{13,14} 6.2 \mathrm{~Hz}, \mathrm{H}-13\right) ; 2.91\left(\mathrm{t}, 2 \mathrm{H}, J_{13,14} 6.2 \mathrm{~Hz}\right.$, H-14), 2.84 (s, 4H, H-17), 2.18, 2.09, 2.04, 2.01 (s, 12H, $\left.\mathrm{COCH}_{3}\right)$; DEPT-135 ${ }^{13} \mathrm{C} \mathrm{NMR}\left(\mathrm{CDCl}_{3} ; 50 \mathrm{MHz}\right): \delta 120.2$; 120.1 (C-11 and C-12); 112.7 (C-9); 101.3 (C-1); 70.7; 70.6 (C-3 and C-5); 68.6 (C-2); 66.8 (C-4); 61.2 (C-6); $55.9\left(\mathrm{OCH}_{3}\right) ; 32.6(\mathrm{C}-14) ; 30.1$ (C-13); 25.5 (C-17); 20.5 $\left(\mathrm{COCH}_{3}\right)$.

To the pure core or dendrimer methanol solution (in this case the methanol was co-destilled with dichloromethane, $3 \times 5 \mathrm{~mL})$ was added dichloromethane $(5 \mathrm{~mL})$. To the resulting solution, it was added a solution of $\mathbf{1 0}(0.1 \mathrm{~g}$, $0.16 \mathrm{mmol}, 1.2$ molar equivalent per terminal amino group) in dichloromethane $(5 \mathrm{~mL})$ with stirring at room temperature. In some cases, the formation of a suspension was observed after about $1 \mathrm{~h}$. In these cases, methanol was dropwise until a solution was obtained. After $3 \mathrm{~h}$, the solvent was removed and the crude was dissolved in methanol. The mixture was cooled in an ice-water bath and a solution of sodium methoxide in methanol was added. The mixture was stirred for $1 \mathrm{~h}$, then acidified to $\mathrm{pH} 7$ by the addition of $1 \mathrm{~mol} \mathrm{~L}^{-1}$ aqueous $\mathrm{HCl}$ and concentrated under reduced pressure. The residue was purified by SEC $\left(1: 1 \mathrm{MeOH} / \mathrm{H}_{2} \mathrm{O}\right)$.

\section{Glycodendrimer 1}

1,4-Butanediamine (5.8 mg, $0.067 \mathrm{mmol}$ ) was used as core. Colorless semi-solid (48 mg, $94 \%$ yield): IR v/cm ${ }^{-1}$ 3675-2992 (amide and alcohol), 1637 and 1554 (amide), 1512 (Aryl); ${ }^{1} \mathrm{H}$ NMR (DMSO-d, $\left.400 \mathrm{MHz}\right) \delta 7.76$ (t, 2H, $J_{\mathrm{a}, \mathrm{NH}} 5.4 \mathrm{~Hz}, \mathrm{~N} \underline{\mathrm{H}}$ 's), 6.96 (d, 2H, $\left.J_{11,12} 8.5 \mathrm{~Hz}, \mathrm{H}-12\right), 6.81$ $\left(\mathrm{d}, 2 \mathrm{H}, J_{9,11} 1.6 \mathrm{~Hz}, \mathrm{H}-9\right), 6.67\left(\mathrm{dd}, 2 \mathrm{H}, J_{9,11} 1.6 \mathrm{~Hz}\right.$ and $J_{11,12}$ $8.5 \mathrm{~Hz}, \mathrm{H}-11$ ), 5.01 (bs, 2H, O-2$), 4.84$ (bs, 2H, Oㅍ-6), 4.79 (d, 2H, J $8.0 \mathrm{~Hz}, \mathrm{H}-1$ ), 4.61 (bs, 2H, Oㅍ-3), 4.50

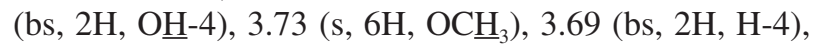
3.53 (m, 2H, H-2), 3.50-3.44 (m, 6H, H-5, H-6 and H-6'), 3.38 (dd, 2H, $J_{2,3} 9.6 \mathrm{~Hz}$ and $\left.J_{3,4} 2.8 \mathrm{~Hz}, \mathrm{H}-3\right), 3.01$ (bq, 4H, $\left.J_{\mathrm{a}, \mathrm{NH}}=J_{\mathrm{a}, \mathrm{b}} 5.4, \mathrm{Ha}\right), 2.74\left(\mathrm{t}, 4 \mathrm{H}, J_{13,14} 7.8 \mathrm{~Hz}, \mathrm{H}-13\right), 2.33$ (t, 4H, $\left.J_{13,14} 7.8 \mathrm{~Hz}, \mathrm{H}-14\right), 1.33$ (bs, 4H, H-b); ${ }^{13} \mathrm{C}$ NMR 
$\left(\mathrm{DMSO}_{6} ; 100 \mathrm{MHz}\right) \delta 171.2(\mathrm{NHC}=\mathrm{O}) ; 148.8(\mathrm{C}-8)$; 144.8 (C-7); 135.1 (C-10); 120.0 (C-11); 115.5 (C-12); 112.8 (C-9); 100.9 (C-1); 75.4 (C-5); 73.5 (C-3); 70.3 (C-2); 68.1 (C-4); $60.3(\mathrm{C}-6) ; 55.6\left(\mathrm{OCH}_{3}\right) ; 38.1(\mathrm{Ca}) ; 37.3(\mathrm{C}-14)$; $30.8(\mathrm{C}-13) ; 26.6(\mathrm{Cb})$; MS-ESI $m / z$ calcd. for $\mathrm{C}_{36} \mathrm{H}_{52} \mathrm{~N}_{2} \mathrm{O}_{16}$ 768.8, found $792.0\left(\mathrm{M}+\mathrm{Na}^{+}\right)$.

\section{Glycodendrimer 2}

Tris(2-aminoethyl)amine ( $6.5 \mathrm{mg}, 0.044 \mathrm{mmol}$ ) was used as core. Amorphous white solid (39 mg, $75 \%$ yield): IR v/ $\mathrm{cm}^{-1}$ 3675-3002 (amide and alcohol), 1636 and 1558 (amide), 1510 (Aryl); ${ }^{1} \mathrm{H}$ NMR (DMSO- $\left.d_{6}, 400 \mathrm{MHz}\right) \delta 7.76$ (t, 3H, $J_{\mathrm{a}, \mathrm{NH}} 5.7 \mathrm{~Hz}, \mathrm{~N} \underline{\mathrm{H}}$ 's), 6.98 (d, 3H, $\left.J_{11,12} 8.4 \mathrm{~Hz}, \mathrm{H}-12\right), 6.83$ $\left(\mathrm{d}, 3 \mathrm{H}, J_{9,11} 1.6 \mathrm{~Hz}, \mathrm{H}-9\right), 6.69\left(\mathrm{dd}, 3 \mathrm{H}, J_{9,11} 1.6 \mathrm{~Hz}\right.$ and $J_{11,12}$ $8.4 \mathrm{~Hz}, \mathrm{H}-11$ ), 5.2-4.3 (m, OH's), 4.81 (d, $3 \mathrm{H}, J_{1,2} 7.6 \mathrm{~Hz}$, $\mathrm{H}-1), 3.74$ (s, 9H, OC$\left.\underline{\mathrm{H}}_{3}\right), 3.72$ (d, $\left.3 \mathrm{H}, J_{3,4} 3.0 \mathrm{~Hz}, \mathrm{H}-4\right)$, 3.59 ( $\mathrm{m}, 3 \mathrm{H}, \mathrm{H}-2)$; 3.55-3.45 (m, 9H, H-5, H-6 and H-6'); 3.41 (dd, $3 \mathrm{H}, J_{2,3} 9.2 \mathrm{~Hz}$ and $J_{3,4} 3.0 \mathrm{~Hz}, \mathrm{H}-3$ ), 3.10 (bq, $6 \mathrm{H}$, $\left.J_{\mathrm{a}, \mathrm{NH}}=J_{\mathrm{a}, \mathrm{b}} 5.7 \mathrm{~Hz}, \mathrm{Ha}\right), 2.77\left(\mathrm{t}, 6 \mathrm{H}, J_{13,14} 7.9 \mathrm{~Hz}, \mathrm{H}-13\right), 2.48$ $\left(\mathrm{t}, 6 \mathrm{H}, J_{\mathrm{a}, \mathrm{b}} 5.7 \mathrm{~Hz}, \mathrm{Hb}\right), 2.39\left(\mathrm{t}, 6 \mathrm{H}, J_{13,14} 7.9 \mathrm{~Hz}, \mathrm{H}-14\right) ;{ }^{13} \mathrm{C}$ NMR (DMSO- $d_{6}$; $\left.100 \mathrm{MHz}\right) \delta 171.4$ (NHC=O); 148.8 (C8); 144.8 (C-7); 135.0 (C-10); 119.9 (C-11); 115.4 (C-12); 112.8 (C-9); 100.8 (C-1); 75.3 (C-5); 73.5 (C-3); 70.3 (C-2); 68.0 (C-4); 60.3 (C-6); $55.6\left(\mathrm{OCH}_{3}\right) ; 53.5(\mathrm{Cb}) ; 37.2(\mathrm{C}-14)$; 36.9 (Ca); 30.7 (C-13); MS-ESI $m / z$ calcd. for $\mathrm{C}_{54} \mathrm{H}_{78} \mathrm{~N}_{4} \mathrm{O}_{24}$ 1166.2, found $1167.3\left(\mathrm{M}+\mathrm{H}^{+}\right)$.

\section{Glycodendrimer 3}

Pentaerythrityltetramine was obtained from the corresponding tetrahydrochloride ( $9.2 \mathrm{mg}, 0.033 \mathrm{mmol}$ ) and sodium bicarbonate ( $29 \mathrm{mg}, 0.29 \mathrm{mmol})$. Dichloromethane was replaced by acetone $(5 \mathrm{~mL}$ ) and water (sufficient amount to dissolve the reactants). Amorphous white solid (38 mg, 78\% yield): IR $v / \mathrm{cm}^{-1} 3691-3022$ (amide and alcohol), 1631 and 1541 (amide), 1511 (Aryl); ${ }^{1} \mathrm{H}$ NMR (DMSO- $\left.d_{6}, 400 \mathrm{MHz}\right) \delta$ 7.68-7.59 (m, 4H, NH's), 6.97 (d, 4H, J $\left.J_{11,12} 8.4 \mathrm{~Hz}, \mathrm{H}-12\right), 6.85$ (s, 4H, H-9), 6.70 (d, 4H, $\left.J_{11,12} 8.4 \mathrm{~Hz}, \mathrm{H}-11\right), 4.98$ (d, $\left.4 \mathrm{H}, J_{\mathrm{OH}-2,2} 4.8 \mathrm{~Hz}, \mathrm{O} \underline{\mathrm{H}}-2\right)$, 4.80-4.78 (m, 8H, $J_{1,2} 7.6 \mathrm{~Hz}, \mathrm{O} \underline{\mathrm{H}}-6$ and $\left.\mathrm{H}-1\right), 4.59$ (bs, $4 \mathrm{H}, \mathrm{O} \underline{\mathrm{H}}-3), 4.45$ (d, 4H, $\left.J_{\mathrm{OH}-4,4} 4.0 \mathrm{~Hz}, \mathrm{O} \underline{\mathrm{H}}-4\right), 3.73$ (s, $\left.12 \mathrm{H}, \mathrm{OC}_{3}\right), 3.67$ (bs, 4H, H-4), 3.59-3.39 (m, 20H, H-2, H-3, H-5, H-6 and H-6'), 2.80 (t, 8H, $J_{13,14} 7.4$ Hz, H-13), 2.72-2.66 (m, 8H, Ha), 2.46 (t, 8H, $J_{13,14} 7.4 \mathrm{~Hz}, \mathrm{H}-14$ ); ${ }^{13} \mathrm{C}$ NMR (DMSO- $\left.d_{6} ; 100 \mathrm{MHz}\right) \delta 172.6(\mathrm{NHC}=\mathrm{O}) ; 148.9$ (C-8); 144.9 (C-7); 134.6 (C-10); 120.0 (C-11); 115.5 (C-12); 112.8 (C-9); 100.9 (C-1); 75.3 (C-5); 73.5 (C-3); 70.3 (C-2); 68.1 (C-4); 60.3 (C-6); $55.6\left(\mathrm{OCH}_{3}\right) ; 39.0$ (Ca); 37.5 (C-14); 30.6 (C-13); MS-ESI $\mathrm{m} / \mathrm{z}$ calcd. for $\mathrm{C}_{69} \mathrm{H}_{96} \mathrm{~N}_{4} \mathrm{O}_{32} 1493.5$, found $769.7\left(\mathrm{M}+2 \mathrm{Na}^{+}\right)$.

\section{Glycodendrimer 4}

A $20 \%(w / w)$ methanol solution of PAMAM dendrimer, 1,4-butanodiamine core, G0 (90 mg of solution, $0.033 \mathrm{~mol}$ ) was used. Crystalline solid (50 mg, 80\% yield): IR $v / \mathrm{cm}^{-1} 3691-2997$ (amide and alcohol), 1635 and 1550 (amide), 1512 (Aryl); ${ }^{1} \mathrm{H}$ NMR (DMSO- $\left.d_{6}, 400 \mathrm{MHz}\right) \delta$ 7.97-7.92 (m, N $\left.\underline{H}^{\prime} \mathrm{s}\right), 6.98$ (d, 4H, $\left.J_{11,12} 8.4 \mathrm{~Hz}, \mathrm{H}-12\right), 6.83$ (d, $\left.4 \mathrm{H}, J_{9,11} 1.6 \mathrm{~Hz}, \mathrm{H}-9\right), 6.69$ (dd, $4 \mathrm{H}, J_{9,11} 1.6 \mathrm{~Hz}$ and $\left.J_{11,12} 8.4 \mathrm{~Hz}, \mathrm{H}-11\right), 5.10-4.45$ (m, $\mathrm{OH}$ 's), 4.81 (d, $\left.4 \mathrm{H}, J_{1,2} 8.0 \mathrm{~Hz}, \mathrm{H}-1\right), 3.75$ (s, 12H, $\left.\mathrm{OC}_{3}\right)$, 3.71 (d, 4H, J $\left.J_{3,4} 3.2 \mathrm{~Hz}, \mathrm{H}-4\right), 3.57$ (m, 4H, H-2), 3.54-3.44 (m, 12H, H-5, H-6 and H-6'), 3.41 (dd, 4H, $J_{2.3} 9.6 \mathrm{~Hz}$ and $J_{3,4} 3.2 \mathrm{~Hz}, \mathrm{H}-3$ ), 3.09 (bs, 16H, Ha and Hb), 2.76 (t, $\left.8 \mathrm{H}, J_{13,14} 7.8 \mathrm{~Hz}, \mathrm{H}-13\right), 2.63\left(\mathrm{t}, 8 \mathrm{H}, J_{\mathrm{c}, \mathrm{d}} 6.8 \mathrm{~Hz}, \mathrm{Hd}\right)$, 2.38-2.34 (m, 12H, He and H-14), $2.20\left(\mathrm{t}, 8 \mathrm{H}, J_{\mathrm{c}, \mathrm{d}} 6.8 \mathrm{~Hz}\right.$, $\mathrm{Hc}), 1.34$ (bs, 4H, Hf); ${ }^{13} \mathrm{C}$ NMR (DMSO- $d_{6} ; 100 \mathrm{MHz}$ ) $\delta 171.6(\mathrm{NHC}=\mathrm{O}$ 's); $148.8(\mathrm{C}-8) ; 144.8(\mathrm{C}-7) ; 135.0$ (C-10); 120.0 (C-11); 115.4 (C-12); 112.8 (C-9); 100.9 (C-1); 75.3 (C-5); 73.5 (C-3); 70.3 (C-2); 68.0 (C-4); $60.3(\mathrm{C}-6) ; 55.6\left(\mathrm{OCH}_{3}\right) ; 52.7(\mathrm{Ce}) ; 49.3(\mathrm{Cd}) ; 38.3(\mathrm{Ca}$ and $\mathrm{Cb}$ ); 37.3 (C-14); $33.2(\mathrm{Cc}) ; 30.7$ (C-13); 24.3 (Cf); MS-ESI $m / z$ calcd. for $\mathrm{C}_{88} \mathrm{H}_{132} \mathrm{~N}_{10} \mathrm{O}_{36} 1906.0$, found 976.2 $\left(\mathrm{M}+2 \mathrm{Na}^{+}\right)$.

\section{Glycodendrimer 5}

A $20 \%(w / w)$ methanol solution of PAMAM dendrimer, 1,12-dodecanediamine core, G0 (108 mg of solution, $0.033 \mathrm{~mol}$ ) was used. Crystalline solid (60 mg, 90\% yield): IR $v / \mathrm{cm}^{-1} 3686-3002$ (amide and alcohol), 1636 and 1549 (amide), 1513 (Aryl); ${ }^{1} \mathrm{H}$ NMR

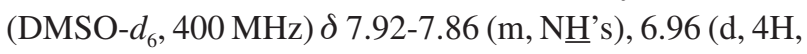
$\left.J_{11,12} 8.2 \mathrm{~Hz}, \mathrm{H}-12\right), 6.81$ (d, 4H, $\left.J_{9,11} 1.6 \mathrm{~Hz}, \mathrm{H}-9\right), 6.66$ (dd, $4 \mathrm{H}, J_{9,11} 1.6 \mathrm{~Hz}$ and $\left.J_{11,12} 8.2 \mathrm{~Hz}, \mathrm{H}-11\right), 5.10-4.40$ (m, $\mathrm{OH}$ 's), 4.78 (d, 4H, J $\left.J_{1,2} 7.6 \mathrm{~Hz}, \mathrm{H}-1\right), 3.73$ (s, 12H, $\mathrm{OCH}_{3}$ ), 3.69 (d, 4H, J $\left.J_{3,4} 3.0 \mathrm{~Hz}, \mathrm{H}-4\right), 3.56$ (m, 4H, H-2), 3.52-3.42 (m, 12H, H-5, H-6 and H-6'), 3.38 (dd, 4H, $J_{2,3} 9.6 \mathrm{~Hz}$ and $J_{3,4} 3.0 \mathrm{~Hz}, \mathrm{H}-3$ ), 3.07 (bs, 16H, Ha and Hb), 2.74 (t, 8H, $\left.\mathrm{H}-13, J_{13,14} 7.8 \mathrm{~Hz}\right), 2.60$ (t, 8H, $\left.J_{\mathrm{c}, \mathrm{d}} 7.0 \mathrm{~Hz}, \mathrm{Hd}\right), 2.36-$ $2.32(\mathrm{~m}, 12 \mathrm{H}, \mathrm{He}$ and $\mathrm{H}-14), 2.17$ (t, 8H, $\left.J_{c, d} 7.0 \mathrm{~Hz}, \mathrm{Hc}\right)$, 1.33 (bs, 4H, Hf), 1.22 (bs, 16H, Hg, Hh, $\mathrm{Hi}$ and $\mathrm{Hj}$ ); ${ }^{13} \mathrm{C}$ NMR (DMSO- $\left.d_{6} ; 100 \mathrm{MHz}\right) \delta 171.5$ (NHE$=\mathrm{O}$ 's); 148.8 (C-8); 144.8 (C-7); 135.0 (C-10); 119.9 (C-11); 115.5 (C-12); 112.8 (C-9); 100.9 (C-1); 75.3 (C-5); 73.5 (C-3); 70.3 (C-2); 68.0 (C-4); 60.2 (C-6); $55.6\left(\mathrm{OCH}_{3}\right)$; $52.8(\mathrm{Ce}) ; 49.4(\mathrm{Cd}) ; 38.3(\mathrm{Ca}$ and $\mathrm{Cb}) ; 37.3(\mathrm{C}-14) ; 33.2$ (Cc); 30.7 (C-13); 29.1 ; 27.0 (Cg, Ch, Ci and $\mathrm{Cj}) ; 26.6$ (Cf); MS-ESI $m / z$ calcd. for $\mathrm{C}_{96} \mathrm{H}_{148} \mathrm{~N}_{10} \mathrm{O}_{36} 2018.3$, found $1010.4\left(\mathrm{M}+2 \mathrm{H}^{+}\right)$. 
Pentaerythrityltetramine tetrahydrochloride 12

A mixture of pentaerythritol $(6.8 \mathrm{~g}, 50 \mathrm{mmol})$ and p-toluenesulfonyl chloride ( $43 \mathrm{~g}, 0.226 \mathrm{~mol})$ in dry pyridine $(75 \mathrm{~mL})$ was stirred for $48 \mathrm{~h}$ under nitrogen atmosphere at room temperature. This mixture was added to $500 \mathrm{~mL}$ of $6 \mathrm{~mol} \mathrm{~L}^{-1}$ aqueous $\mathrm{HCl}$. The resulting white precipitate was filtered and washed with methanol $(300 \mathrm{~mL})$ to afford pentaerythritol tetratosylate (34 g, 90\% yield) which was used without further purification.

A mixture of pentaerythritol tetratosylate 11 (3.0 g, $4.0 \mathrm{mmol})$, sodium azide $(3.0 \mathrm{~g}, 48 \mathrm{mmol})$ in DMF $(30 \mathrm{~mL})$ was stirred for $20 \mathrm{~h}$ at $100{ }^{\circ} \mathrm{C}$. This mixture was added to $200 \mathrm{~mL}$ of water and extracted with diethyl ether $(4 \times 40 \mathrm{~mL})$. The combined organic layers were dried with anhydrous sodium sulfate, filtered and concentrated to about $30 \mathrm{~mL}$. Dioxane (15 mL) was added and the solution was concentrated again to about $30 \mathrm{~mL}$. Dioxane $(15 \mathrm{~mL})$, triphenylphosphine $(6.3 \mathrm{~g}, 24 \mathrm{mmol})$ and 28-30\% (w/w) aqueous ammonium hydroxide $(22 \mathrm{~mL})$ were added and the mixture was stirred at room temperature for $48 \mathrm{~h}$. The solvent was removed by air jet and chloroform $(60 \mathrm{~mL})$ was added to the resulting white solid. The mixture was extracted with $3 \mathrm{~mol} \mathrm{~L}^{-1}$ aqueous $\mathrm{HCl}(5 \times 15 \mathrm{~mL})$. The combined aqueous layers were concentrated to about $15 \mathrm{~mL}$ and $37 \%$ (w/w) aqueous $\mathrm{HCl}(2 \mathrm{~mL})$ was added. The resulting suspension was filtered and washed with ethanol and diethyl ether. Compound $\mathbf{1 2}$ was obtained as an amorphous white solid ( $0.76 \mathrm{~g}, 62 \%$ yield, 3 steps ): IR $\mathrm{v} / \mathrm{cm}^{-1} 3124$ and 1582 (amine), 2988 and 2863 (aliphatic); ${ }^{1} \mathrm{H}$ NMR $\left(\mathrm{D}_{2} \mathrm{O}, 200 \mathrm{MHz}\right) \delta 3.43\left(\mathrm{~s}, 8 \mathrm{H}, \mathrm{CH}_{2}\right) ;{ }^{13} \mathrm{C} \mathrm{NMR}$ $\left(\mathrm{D}_{2} \mathrm{O} ; 50 \mathrm{MHz}\right) \delta 38.6\left(\mathrm{CH}_{2}\right)$.

\section{Supplementary Information}

Supplementary data are available free of charge at http://jbcs.sbq.org.br, as PDF file.

\section{Acknowledgments}

We are thankful to Fundação de Amparo à Pesquisa do Estado de Minas Gerais (FAPEMIG), Conselho Nacional de Desenvolvimento Científico e Tecnológico (CNPq) and Coordenação de Aperfeiçoamento de Pessoal de Nível Superior (CAPES) for financial support and fellowships and to Professor Renata Barbosa de Oliveira for providing Sephadex LH-20.

\section{References}

1. Roy, R.; Baek, M.-G.; Rev. Mol. Biotechnol. 2002, 90, 291.

2. Lee, Y. C.; Lee, R. T.; Acc. Chem. Res. 1995, $28,321$.

3. Lundquist, J. J.; Toone, E. J.; Chem. Rev. 2002, 102, 555.

4. Krist, P.; Vannucci, L.; Kuzma, M.; Man, P.; Sadalapure, K.; Patel, A.; Bezouska, K.; Pospisil, M.; Petrus, L.; Lindhorst, T. K.;

Krem V.; ChemBioChem 2004, 5, 445.

5. Baek, M.; Roy R.; Bioorg. Med. Chem. 2002, 10, 11.

6. Lee, R. T.; Lee, Y. C.; Glycoconj. J. 2000, 17, 543.

7. Maierhofer, C.; Rohmer, K.; Wittmann, V.; Bioorg. Med. Chem. Lett. 2007, 15, 7661.

8. Deguise, I; Lagnoux, D.; Roy, R.; New J. Chem. 2007, 31, 1321.

9. Toucubia, M.; Wellens, A.; Shiao, T. C.; Wang, Q.; Sirois, S.; Bouckaert, J.; Roy, R.; ChemMedChem 2007, 2, 1190.

10. Rajakumar, P.; Anandham, R.; Eur. J. Med. Chem. 2011, 46, 4687.

11. Turnbull, W.C.; Stoddard, J. F.; Rev. Mol. Biotechnol. 2002, 90 , 231.

12. Ashton, P. R.; Boyd, S. E.; Brown, C. L.; Nepogodiev, S. A.; Meijer, E. W.; Peerlings, H. W. I.; Stoddart, J. F.; Chem. Eur. J. 1997, 3, 974.

13. Adil, K.; Goreshnik, E.; Couran, S.; Dujardin, G.; Leblanc, M.; Maisonneuve, V.; Solid State Sci. 2004, 6, 1229.

14. Ding, P.; Chu, X.; Cai, M.; Yu, D.; Acta Pharm. Sinica 1997, 32,755 .

15. Orth, R.; Pitsheider, M.; Sieber, S. A.; Synthesis 2010, 13, 2201.

16. Cateni, F.; Bonivento, P.; Procida, G.; Zacchigna, M.; Scialino, G.; Banfi, E.; Bioorg. Med. Chem. Lett. 2007, 17, 1971.

17. Beejmohun, V.; Grand, E.; Mesnard, F.; Fliniaux, M.; Kovensky, J.; Tetrahedron Lett. 2004, 45, 8745.

18. Percec, V.; Peterca, M.; Sienkowska, M. J.; Ilies, M. A.; Aqad, E.; Smidrkal, J.; Heiney, P. A.; J. Am. Chem. Soc. 2006, 128, 3324.

19. Wada, A.; Tamaru, S.; Ikeda, M.; Hamachi, I.; J. Am. Chem. Soc. 2009, 131, 5321.

20. Roy, R.; Kim, J. M.; Tetrahedron 2003, 59, 3881.

21. Vadehra, G. S.; Wall, B. D.; Diegelmann, S. R.; Tovar, J. D.; Chem. Commun. 2010, 46, 3947.

Submitted: December 14, 2011

Published online: May 10, 2012 


\title{
Additions and Corrections
}

\section{An Efficient Synthesis of D-Galactose-Based Multivalent Neoglycoconjugates}

\author{
Saulo F. de Andrade, ${ }^{a}$ Rute C. Figueiredo, ${ }^{b}$ José D. de Souza Filho ${ }^{a}$ and Ricardo J. Alves ${ }^{*, b}$ \\ ${ }^{a}$ Departamento de Química, Instituto de Ciências Exatas and ${ }^{b}$ Faculdade de Farmácia, \\ Universidade Federal de Minas Gerais, Av. Antônio Carlos, 6627, 31270-901 Belo Horizonte-MG, Brazil
}

Vol. 23, No. 6, 1062-1069, 2012.

http://dx.doi.org/10.1590/S0103-50532012000600010

Page 1062, line 3: Second author address change

Saulo F. de Andrade, ${ }^{a}$ Rute C. Figueiredo, ${ }^{c}$ José D. de Souza Filho ${ }^{a}$ and Ricardo J. Alves ${ }^{*, b}$

${ }^{a}$ Departamento de Química, Instituto de Ciências Exatas and ${ }^{b}$ Faculdade de Farmácia, Universidade Federal de Minas Gerais, Av. Antônio Carlos, 6627, 31270-901 Belo Horizonte-MG, Brazil

${ }^{c}$ Universidade Federal de Ouro Preto, Campus Morro do Cruzeiro, s/n, Bairro Bauxita, 35400-000 Ouro Preto-MG, Brazil. 